\title{
THE JAVA CALENDAR AND ITS RELEVANCE WITH THE ISLAMIC CALENDAR
}

\author{
Faiz Farichah
}

Sekolah Tinggi Agama Islam Al-Muhammad, Cepu

faiz.aidafahd@gmail.com

\begin{abstract}
Calendar or calendar system is an important reference for mankind from ancient times to the present. Judging from the reference system, there are three types of calendars, namely solar-based, lunar-based and both-based calendars. Meanwhile, in terms of its complexity, the calendar is divided into two, namely the astronomical and arithmetic calendars. The Javanese calendar after the changes made by the great sultan, was inspired by the hijri calendar. Both are based on the lunar calendar. The aim of this study is to introduce the calendar system, the Javanese calendar and its relevance to the hijriah calendar, and the Javanese Aboge calendar. This research is descriptive. The source in this research study is literature review. From this research it was found that the hijri calendar is an astronomical calendar that requires observation and has a high degree of accuracy with respect to the visibility of the new moon, while the Javanese calendar is an arithmetic calendar system, so it requires corrections in a certain period to be the same or nearly the same as the hijri calendar. However, the Aboge calendar does not change curves or cycles, so that the Aboge Javanese calendar has a difference of days with the Javanese calendar currently in use, namely the calendar with the asapon calendar, and it could be the same or the difference of up to two days with the Hijri calendar. Yet the calendar is used by the Javanese not only for worship, but also for petungan in determining traditional ceremonies and personal interests.
\end{abstract}

Keywords: Calendar, Hijriyah Calendar, Javanese Calendar, Aboge.

\section{Abstrak}

Kalender atau sistem penanggalan merupakan suatu acuan yang penting bagi umat manusia dari zaman dahulu hingga kini. Dilihat dari sistem acuannya, kalender terdapat tiga jenis, yakni kalender berbasis matahari, berbasis bulan, dan berbasis keduanya. Sedangkan ditinjau dari tingkat kerumitannya, kalender terbagi menjadi dua, yakni kalender astronomik dan aritmatik. Kalender Jawa setelah adanya 
perubahan yang dilakukan oleh sultan agung, terinspirasi dari kalender hijriah. Keduanya sama-sama berbasis pada peredaran bulan (lunar calendar).Tujuan penelitian ini adalah sebagai perkenalan terhadap sistem kalender, kalender jawa dan relevansinya dengan kalender hijriah, serta kalender jawa aboge. Penelitian ini bersifat deskriptif. Adapun sumber dalam kajian penelitian ini adalah kajian pustaka. Dari penelitian ini ditemukan bahwa kalender hijriah merupakan kalender astronomik yang memerluhkan pengamatan dan memiliki tingkat keakuratan tinggi terhadap visibilitas hilal, sedangkan kalender jawa merupakan sistem kalender aritmatik, sehingga memerluhkan koreksi dalam periode tertentu agar bisa sama atau hampir sama dengan kalender hijriah. Namun, pada kalender aboge, tidak melakukan ganti kurup atau siklus, sehingga membuat kalender jawa aboge memiliki selisih hari dengan kalender jawa yang saat ini digunakan yakni kalender dengan kurup asapon, dan bisa jadi sama atau selisih hingga dua hari dengan kalender hijriah. Padahal kalender digunakan oleh orang jawa tidak saja untuk ibadah, juga untuk petungan dalam menentukan upacara-upacara adat dan kepentingan pribadi.

Kata Kunci : Kalender, Kalender Hijriah, Kalender Jawa, Aboge.

\section{A. Introduction}

Calendar is the important thing in human life. ${ }^{1}$ Both the astronomical calendar, which is determined based on the movement of celestial bodies, and the nonastronomical calendar, which uses celestial bodies only as a reference for determining and calculating. ${ }^{2}$ Allah says:

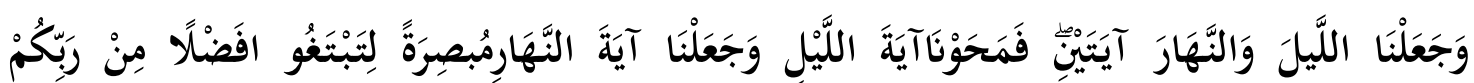

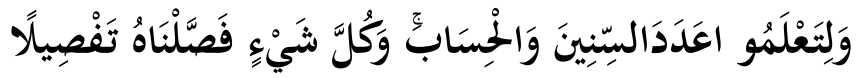

\footnotetext{
${ }^{1}$ Butar-butar, Kalender sejarah dan Arti Pentingnya, 17

At least there are four calendar urgencies in human life, including:

1) Recording of various moments and phenomena. Which is usually recorded in the format of the day, date, month and year. Namely:

- Astronomical phenomena, such as the beginning of the year.

- Unique phenomenon, such as an earthquake.

- Historical moments experienced by humans in social life.

- Upcoming socio-religious moments, such as religious rituals, school schedules, and so on.

2) An annual phenomenon recorder. Such as prayer times, certain seasons, historical moments such as Eid. Where this recording is generally owned by each person and hung in their respective homes.

3) Standard time for various transactions, such as savings and loan transactions along with estimated interest and maturities, house contracts, and so on

4) Reconstruction of someone's notes. For example, Sandi was declared born on Thursday legi, 10 November 1989. By using the comparison of the dates it is known that the mutilation on Thursday 10 November 1989 is wrong, the correct one is Friday pahing.

${ }^{2}$ Muh. Nasiruddin, Kalender Hijriah Universal, Kajian atas sitem dan prospeknya di Indonesia, (Semarang: Al-wafa, 2013), 28
}

Al-Hilal: Journal of Islamic Astronomy, Vol. 2, No. 2, Tahun 2020

p-ISSN : 2775-1236 ; e-ISSN : 2775-2119 
"And we made the night and day two signs, then we erased the sign of the night and made the sign of the day light, that you may seek gifts from your God, and that you might know the number of years and the number of years and calculations. And everything we have explained clearly. "(Q.S. Al-Isra'/17: 12). ${ }^{3}$

Along with the advancement of civilization with considerations such as agriculture (economy), travel (business), religion and culture, which was motivated by the socio-political demands of the era, a natural means of timing was needed, namely the reason why humans were motivated to compile a calendar. by observing one or more phenomena periodically and for a long time so that they become a recurring phenomenon. The repetition of this natural phenomenon then makes time scheduling or calendar ${ }^{4}$ included in astronomical studies, ${ }^{5}$ because the problem of time is based on the rotation of the earth on its axis and its circulation in orbit around the sun, ${ }^{6}$ as well as the circulation of the moon around the earth.

Pre-Islamic Arab countries did not yet have an official and unified calendar system for inter-tribal use. Generally, people at that time provided calendars based on various events or events related to certain numbers. For example the birth of the Prophet Muhammad is declared to be born in the year of the Elephant, the birth of Abu Bakr, three years after the year of the Elephant. The pre-Islamic Arabic calendar is still approximate. $^{?}$

After Islam entered, the Prophet Muhammad changed the calendar from the An-Nasi calendar which is sometimes 13 months to the qamar calendar which is 12 months old, but still does not use the number of years. The Prophet's calendar is called the Islamic calendar.

\footnotetext{
${ }^{3}$ Al-Qur'an dan terjemahannya, 426

${ }^{4}$ Arwin Juli Rakhmadi Butar-butar, Kalender sejarah dan Arti Pentingnya dalam Kehidupan, (Semarang: bisnis Mulia Konsultama, 2014), 14.

${ }^{5}$ Astronomy is defined as a scientific study of the horizon that uses the rules of attention, attention, estimation, interpretation of dimensional position theory, sprinkles, movement, composition, and the evolution of planets, comets, stars and celestial phenomena.

See, Aizan Ali Mat Zin, Sejarah Astronomi Islam di Malaysia, (Kuala Lumpur: Universiti Malaya, 2017), 1-2

${ }^{6}$ Abdul Hamid Tahir, Unsur-unsur Astronomi Praktik untuk Kegunaan Ukur Tanah, (Melaka: Syarikat Percetakan Muncul System, 1990), 65

${ }^{7}$ Years are not in numbers, but based on an event that could occur before, during, or after the event. So it becomes more difficult to ascertain its validity.
} 
The Islamic calendar or calendar that is meant here is any calendar system which is basically based on the teachings of Islam. ${ }^{8}$ In this case the Islamic calendar is usually called the kamariyah calendar, and it is also called the Hijri calendar. ${ }^{9}$ HIjriah calendar is a calendar consisting of 12 months of kamariyah; each month from the first sighting of the crescent moon to the next, ${ }^{10}$ or from the conjunction to the next conjunction. ${ }^{11}$

The Hijri calendar is said to be the Islamic calendar at least from several indications, first, the Hijri calendar is an Islamic calendar that begins with the Prophet's hijrah event, ${ }^{12}$ secondly, this Islamic calendar was introduced and an effort was made to rationalize various calendar systems to become the Hijri calendar by Umar bin Khattab, who is a the second Successor after the death of the Prophet. ${ }^{13}$ Third, this rationalization is inseparable from instructions and guidance on the main points of understanding the kauniyah verse in determining the beginning of the month. ${ }^{14}$ Fourth, the renewal of the Javanese calendar by Sultan Agung, from a Sun-based calendar to a Moon-based calendar, was inspired by the hijriyah calendar, one of which was in the framework of Islamic da'wah. so that the changes made do not cause rejection. ${ }^{15}$ Thus, the next writer wrote with the term Hijri calendar which means the Islamic calendar.

At a time when Muslims were only centered in Mecca and Medina, the need for a calendar was not felt yet, but when the expansion of Islam expanded to other areas, the need for scheduling (calendars) became increasingly necessary. Is Abu Musa alAsy'ari, he wrote a letter to Umar bin Khattab, stating that he received an undated letter, even though the letter was recorded as the month of Sha'ban, but when, in what year, it is unclear. ${ }^{16}$

\footnotetext{
${ }^{8}$ Ruswa Darsono, Penanggalan Islam Tinjauan Sistem, Fiqih dan Hisab Penanggalan, (Yogyakarta: Labda Press, 2010), 65

${ }^{9}$ Susiknan Azhari, Ensiklopedi Hisab Rukyat, (Yogyakarta: Pustaka Pelajar, 2012), 118

${ }^{10}$ Susiknan Azhari, Penggunaan Sistem Hisab dan Rukyat di Indonesia (Studi tentang Interaksi NU dan Muhammadiyyah), (Yogyakarta: Disertasi UIN Sunan Kalijaga, 2006), 22-23

${ }^{11}$ Akhmad Nadirin and M. Ihtirozun Ni'am, "Date Correction Of Omar Bin Khattab's Death In An Astrnomical Perspective,” Al-Hilal:Journal of Islamic Astronomy 1 (2019): 94.

${ }^{12}$ Susiknan Azhari, Penggunaan,.. 23

${ }^{13}$ Ahmad Izzuddin, Sistem Penanggalan, (Semarang: CV Karya Abadi Jaya, 2015), 65

${ }^{14}$ Anisah Budiwati, Formulasi Kalender Hijriah Dalam Pendeatan Historis-Astronomis, (Semarang: Disertasi UIN Walisongo, 2019), 181

${ }^{15}$ Ruswa Darsono, Penanggalan,.. 92

${ }^{16}$ Arwin Juli Rakhmadi Butar-butar, Kalender Islam, Lokal ke Global, Problem dan Prospek,(Medan: OIF Umsu, 2016), 23
} 
Due to this phenomenon, the Umar bin Khattab took deliberations to address the administrative problems related to this calendar, ${ }^{17}$ so that a calendar emerged whose reference was as taught by the Prophet Muhammad. This determination occurred in the year $17 \mathrm{H} / 638 \mathrm{AD}$. It is called the hijriah calendar because it was determined from the time the Prophet moved from Mecca to Medina, ${ }^{18}$ and used the number of years in which the prophet migrated, as suggested by Ali bin Abi Talib ra. ${ }^{19}$

Around one thousand and eighteen years after the birth of the hijri calendar, namely in 1035 hijriyah, Sultan Agung combined the hijriah calendar and the saka calendar calculation system previously used by the Javanese. The year grows in years, but the system is inspired by the hijriah calendar, but not by looking at the new moon, only estimates. The calendar which is known as the Javanese calendar was decided in the year 1625 AD / 1547 Saka / 1035 Hijriah.

The Javanese actually use two calendars, which are month-based as mentioned above, and the pranotomongso calendar which is sun-based. The Javanese calendar is more used as a ritual and custom, while the pranotomongso calendar is more used as a sign in agriculture.

The Javanese calendar is divided into two major periods, namely the period after the influence of Islam, and the period when the calendar is influenced by Hinduism, the Javanese calendar is interesting, for several reasons, including; This calendar uses simple calculations which is consistent in calculation, the Javanese calendar is also used for customs-related interests, whether related to society or personal interests such as marriage. This calendar is important for Javanese society, because it carries out traditions such as wetonan, nyadran, mitoni, and so on. What distinguishes it from other calendars, in the Javanese calendar, apart from days, there is also Pancawarna / Pasaran. From this Pancawarna / Pasaran day came the term weton which for Javanese people who know what is important related to the 'calculation of the direction' of their life. The Javanese people who are Javanese may have started to decline, but some traditions in Kejawen are still inherent in society today.

\footnotetext{
${ }^{17}$ Slamet Hambali,Almanak Sepanjang Masa, (Semarang: Program Pascasarjana IAIN Walisongo, 2011),

${ }^{18}$ Ahmad Izzuddin, Sistem Penanggalan, (Semarang: Karya Abadi, 2015), 66

${ }^{19}$ Butar-butar,Kalender Islam.., h. 24
} 
The Javanese calendar, even though the year uses the Saka year, is different from the Saka calendar used by Hindus, because the Saka year comes after Nyepi. Meanwhile, the Javanese New Year coincides with the Hijri calendar. And although the Javanese calendar is inspired by the Hijri calendar, which means the two are similar, its use for Indonesians is a little different. The identical hijri calendar is used for religious purposes, while the Javanese calendar is identical for customary purposes.

\section{B. Method}

This research is a research library with a descriptive analysis approach. The author collects data related to the Javanese calendar and the Islamic calendar, then looks for relevance between the two. In this case, the results of the calculation of the beginning of the year for each calendar system will be explained, so that the relevance value can be found.

\section{Discussion and Results}

\section{C.1. Calendar Concept}

The term calendar is very familiar among personal and social circles as a primary need in all activities, as well as a reflection of the power and strength of a civilization. ${ }^{20}$ Calendar has a meaning synonymous with list of days and pasaran. ${ }^{21}$ In Arabic it is called almanac, ${ }^{22}$ takwim, ${ }^{23}$ or date. ${ }^{24}$ Whereas in English, it is called a calendar, which is a variety of systems that show days grouped into various periods to regulate civil, religious and scientific matters. ${ }^{25}$

${ }^{20}$ Muh. Hadi bashori, Penanggalan Islam, Peradaban tanpa Penanggalan, Inikah pilihan kita?, (Jakarta: Gramedia, 2013), 7

${ }^{21}$ Muh Rasywan Syarif, Perkembangan Perumusan Kalender Islam Internasional,( Disertasi UIN Sunan Kalijaga Yogyakarta, 2017), 32

${ }^{22}$ Susiknan Azhari, Ensiklopedi Hisab Rukyat, (Yogyakarta: Pustaka Pelajar, 2012), h. 29

The almanac is a list of the days, weeks, months of holidays of the year.

${ }^{23}$ Taqwim means to correct, balance and limit

${ }^{24}$ Date means knowing and limiting time

Tasnim Rahman Fitra, Fikih of the Unifikatif Hijriah calendar, http://www.istinbath.or.id, 2018: 261, accessed on 10 February 2020, doi: https: //doi.org/10.20414/ijhi,v17i2.96.

${ }^{25}$ Astronomy defined and explained, Collins Dictionary of Astronomy, (British: The Macmillan Dictionary, 2012), 57

Calendar, any of various present day, past, or proposed systems for the reckoning of time over extended periods: Days are grouped into various periods that are suitable for regulating civil life, fixing religious observances, and meeting scientific needs 
Etymologically, the word calendar comes from the root word in French, namely calendier, which is an uptake of the Latin calendarium which means money lender's notebook, or also means the first day of every month.

In terms of terminology, according to Ali Hasan Musa, it is stated that the calendar is the calculation and division of times in units of time such as years, months, weeks, and days based on certain phenomena to be used as guidance, signs and rules for human activity at all times. ${ }^{26}$

Meanwhile, according to Susiknan Azhari, it was written that the calendar is a system of organizing time units, for the purpose of collecting data and calculating time in the long term. Calendar is closely related to human civilization, because it plays an important role in determining the time of hunting, farming, worship and celebrations. ${ }^{27}$

The birth of a calendar is closely related to the study of astronomy and the advancement of the civilization of a nation and its social complexity, thus giving birth to the calendar as a manager and scheduler of both social, administrative, ritual and religious time. For example, the Egyptian civilization made the phenomenon of the flood of the Nil river and the appearance of the Sirius star that occurred repeatedly, and was used as a sign. Therefore the calendar emerged at the same time as the astronomical tradition. Not only by looking at natural phenomena, calendar, it can also be observed from the instincts of animals that in their activities use a certain schedule, which is regular and fixed. ${ }^{28}$

Apart from that, the calendar also appeared as a result of human activities, such as planting seeds, raising livestock and sailing. ${ }^{29}$ including in Islam, the birth of the calendar is closely related to religious interpretations (fiqh) which are in touch with the

${ }^{26}$ Tasnim Rahman Fitra, Fiqih Astronomi Hijriah Unifikatif, hal 361

27 Susiknan Azhari, Ensiklopedi Hisab-Rukyat.., h. 115

${ }^{28}$ For example, birds that move from one area to another, and come back to that area at a certain time. When winter occurs in the northern hemisphere, the southern hemisphere will experience summer. Then the birds in the north will move to the south with standard weather for them, and will return to the southern region when the weather has changed. In fact, to move places it takes up to thousands of miles. In addition, there are also animals that have a habit of sleeping in the winter season, and doing activities in the summer, and so on.

${ }^{29}$ Anisah Budiwati, Formulasi Kalender Hijriah dalam Pendekatan Historis-Astronomis, (Disertasi, Universitas Islam Negeri Semarang, 2019), 73 
interpretation of science. ${ }^{30}$ Broadly speaking, the calendar was built for identification, planning, and timing.

In the Encyclopedia Britannica, the calendar system that has developed in the world from ancient times to modern times, including 1) the primitive calendar system, (2) the western calendar, (3) the Chinese calendar, (4) ) Egyptian calendar, (5) Indian calendar, (6) Babylonian calendar, (7) Jewish calenari, (8) Greek calendar, (9) ) Islamic calendar (10), Central American calendar (MiddleAmerican caledar). ${ }^{31}$

The ten calendar systems have different rules for determining calendar rules and so on. Meanwhile, in Fraser's research in 1987, there are about 40 calendar systems in the world. ${ }^{32}$

The calendar is inseparable from the three objects, the earth, moon and sun, although some calendars refer to the stars. Therefore, this calendar comes from three bases of the calendar reference system, there are:

1. Solar Calendar

The solar calendar is a calendar that calculates or refers to the sun. In principle, this system is a dating system that uses the earth's journey as it evolves or orbits the sun. ${ }^{33}$ Usually, it has about 365.2425 days or 365 days 5 hours 48 minutes 2.8 seconds $^{34}$ in one play or one year. The advantages can be used to determine the changes in the annual seasons, ${ }^{35}$ which are caused by an elliptical orbit around the sun, and see the movement of the sun throughout the year between the thirteen ecliptic constellations. ${ }^{36}$

The models of the solar calendar include the ancient Egyptian calendar, the ancient Roman calendar, the Mayan calendar, the Julian calendar, the Greek calendar, the Japanese calendar.

\section{Lunar Calendar}

${ }^{30}$ Butar-Butar, kalender Sejarah.., h. 14

${ }^{31}$ Susiknan Azhari and Ibnar Azil Ibrahim, kalender Jawa Islam:Memaduan Tradisi dan Tuntunan Syar'i, Jurnal Asy-Syir'a, vol 42 no.1 , (2008): 131, accessed on 27 February 2020, doi:

32 Bashori, Penanggalan Islam, hal. 2

${ }^{33}$ Hambali,Almanak Sepanjang Masa, 3

${ }^{34}$ Hambali,Almanak Sepanjang Masa, 27

${ }^{35}$ Nashiruddin, Kalender Hijriah Universal, 30

${ }^{36}$ Nashiruddin, Kalender Hijriah Universal, 30 
The Moon Calendar is a calendar that makes the moon's journey around the earth (evolves towards the earth) as the basis for its calculations, it uses the phases of the moon's changes as a reference for its time. ${ }^{37}$ Moon travel or moon manzilah is called in qs. Yasin: 39, where when the moon rises at the beginning of the month, only a little moonlight is visible and the day it looks brighter and after it is perfectly round, the day it gets smaller and dimmer. ${ }^{38}$ The moon phase occurs, because the moon does not emit its own light, but it is visible from the earth because it receives light from the sun. ${ }^{39}$

There are two types of moon travel time around the earth, namely sideris months and synodic months. ${ }^{40}$ The circulation of the moon or the revolution of the moon around the earth in one synodic month or ash-syahr an-nujumi is $27 \mathrm{~h}$

\footnotetext{
${ }^{37}$ The moon rotates around its axis at the same speed as it does around the earth. That's why the moon always faces the earth with one face. During the circulation of the position of the earth and the moon towards the sun changing, this change is scientifically given the term phases of the moon, also called the terms preceding qamar or faces of the moon.

See, Kadir, Formula Baru Ilmu falak Penduan Lengkap Ë Praktis, (Jakarta: Amzah, 2012), 33.

See also, Muhyiddin Khazin, 99 Tanya Jawab masalah Hisab $\mathscr{E}$ Rukyat, (Yogyakarta: Ramadhan Press, 2009), 78

${ }^{38}$ Muhammad Faizal bin Jani, Ilmu Falak Fi Ithna Asyara Syahran, (Malaysia: tt), 77-80

In general, the phases of the moon consist of: Hilal, young moon, full moon, old moon, and dark moon. In more detail, the phases of the moon include:

- New moon phase (new moon)

- Phase crescent moon (hilal or crescent)

- Full moon phase (tarbi'ul Awal or first quarter)

- The phase of the hunchback moon (young moon)

- Full moon phase (full moon or badri)

- Back in the phase of the humpback moon (old moon), the moon is getting narrower, humpbacked, half full again (tarbi'ul as-sani or last quarter), then in the shape of a crescent, until it reaches the dead moon (muhak). From the new moon to the moon full moon is called the rising moon. Meanwhile, from the full moon to the new moon it is called the receding moon.

More specifically, Imam al-qurtubi when interpreting qs. Yasin: 39, states that Allah made 28 manzilah for the month:

$\begin{array}{lll}\text { 1. Al-Syartan } & \text { 2. Al-Butain } & \text { 3. Al-Thurayya } \\ \text { 4. Al-Dabaran } & \text { 5. Al-Haq'ah } & \text { 6. Al-Han'ah } \\ \text { 7. Al-Dzira } & \text { 8. Al-Nasrah } & \text { 9. Al-Tarf } \\ \text { 10. Al-Jabhah } & \text { 11. AL-Kharatan } & \text { 12. AL-Sarfah } \\ \text { 13. Al-Awwa' } & \text { 14. Al-Simak } & \text { 15. Al-Ghafr } \\ \text { 16. Al-Zabanayan } & \text { 17. Al-lklil } & \text { 18. AL-Qalb } \\ \text { 19. Al-Syaulah } & \text { 20. AL-Naa'im } & \text { 21. Al-Baladdah } \\ \text { 22. Sa'd al-dzabih } & \text { 23. Sa'd Bula' } & \text { 24. Sa'd al-su'ud } \\ \text { 25. Sa'd al-Akhbiyyah } & \text { 26.Al-fargu al-muqaddam } \\ \text { 27. Al-Fargu al-muakkhar } & \text { 28. Batnu Al-Hut }\end{array}$

See also, F. fatwa Rosyadi S. Hamdani, Ilmu Falak Menyelami makna hilal dalam al-qur'an, (Bandung: Unisba, 2017), 53-57

${ }^{39}$ Azhari, Ensiklopedi Hisab Rukyat, 174

${ }^{40}$ Baharriddin Zainal, Ilmu Falak, (Selangor: Dawama Sdn. Bhd., 2004), 61
} 
$7 \mathrm{~h} 43 \mathrm{~m} 12 \mathrm{~d}$ or 27.321661 days in one turn or one month. However, what is used in determining the calendar is the synodic time or asy-syahr al-iqtirani or ad-da'iri, which is the time it takes for the moon to circle the earth from ijtima 'to the next ijtima', the average length of which is $29 \mathrm{~h} 12 \mathrm{~h} 44 \mathrm{~m} 3 \mathrm{~d}$ or 29.530589 days in one turn or one month, ${ }^{41}$ or an average of 354.367068 days or 354 days 48 minutes 34 seconds, ${ }^{42}$ in one year. This month's calendar model includes; Hijri calendar and Javanese calendar.

3. The solar-moon calendar

The solar-moon calendar is a lunar (lunar) calendar according to the sun. ${ }^{43}$ The Moon-Sun calendar is a standard combined calendar system between the movement of the moon around the earth (lunar calendar) with the solar annual pseudo cycle (solar calendar) for the calculation of months and years. ${ }^{44}$ The calculation, one year in the solar-lunar calendar is equal to one year in the solar calendar, but the change of the moon is adjusted to the period of the phases of the moon, it is calculated from newmoon to the next newmoon, so that the number of days is 354 days in a year, or a year 12 months with 29- 30 days. However, in 19 years, there are 7 times (years) that are inserted with an additional month (intercalary mounth) or consisting of 13 months, ${ }^{45}$ so that the calendar is adjusted by the length of the solar tropical cycle. The advantages of this calendar are consistency with changing seasons and consistency in changing shape of the month. ${ }^{46}$

Pre-Islamic Arabs also used a calendar with this system, but not all Arab tribes agreed to determine which year had a rice month '(intercalation). One tribe determines thenasi' month in a certain year, while other tribes determine in a

${ }^{41}$ Nashiruddin, kalender Hijriah Universal, 31

${ }^{42}$ Hambali, Almanak Sepanjang Masa, 13

${ }^{43}$ Ma'rifat Iman, Kalender pemersatu Dunia Islam,(Jakarta: Gaung Persada Press, 2010), 19

${ }^{44}$ Anisah budiwati, formulasi Kalender Hijriah dalam PendekatanHistoris-Astronomis,(Disertasi, UIN Walisongo Semarang, 2019), h. 100

45 This is because in the solar calendar there are 365 days, while in the luni-solar calendar there are 354 days, meaning that there is a difference that is faster than it should be 11 days. So to adjust the number of days with the movement of the sun, there are leap years and intercalated years which consist of 13 months 7 times in 19 years, namely in years 3, 6, 8, 11, 14, 17 and 19. In words another, in 19 years there are 235 months consisting of 228 months plus 7 months of insertion.

${ }^{46}$ Nashiruddin, Kalender Hijriah Universal, 35 
different year. As a result, if the tribesmen did not put down the nasi' month. it means they were prohibited from fighting in that month, while the tribes who determined the nasi' month would be free to fight. Hence this extra month caused a lot of enmity among Arabs. ${ }^{47}$ Until Q.S At-Taubah (9): 36-37 came down, ${ }^{48}$ and since then Muslims have used a month-based calendar.

The models of this solar-moon calendar are the an-Nasi calendar, the Babylonian calendar, the Jewish calendar, the Chinese calendar.

Of the 3 calendar reference systems above, in general, they can be divided into: $^{49}$

\begin{tabular}{|c|c|c|c|}
\hline No & Description & System & Information \\
\hline \multirow{3}{*}{1} & \multirow{3}{*}{$\begin{array}{l}\text { Determination } \\
\text { of day }\end{array}$} & Solar & Sun \\
\hline & & Lunar & Moon \\
\hline & & Luni-solar & Sun and Moon \\
\hline \multirow[t]{3}{*}{2} & \multirow{3}{*}{$\begin{array}{l}\text { Determination } \\
\text { of day }\end{array}$} & Solar & At 00.00 \\
\hline & & Lunar & When the sun goes down \\
\hline & & Luni-solar & When the sun goes down \\
\hline \multirow[t]{3}{*}{3} & \multirow{3}{*}{$\begin{array}{l}\text { The number of } \\
\text { days in a year }\end{array}$} & Solar & $365-366$ \\
\hline & & Lunar & $354-355$ \\
\hline & & Luni-solar & $354-383$ \\
\hline \multirow[t]{3}{*}{4} & \multirow{3}{*}{$\begin{array}{l}\text { The number of } \\
\text { days in a month }\end{array}$} & Solar & $28-31$ \\
\hline & & Lunar & $29-30$ \\
\hline & & Luni-solar & $29-30$ \\
\hline \multirow[t]{3}{*}{5} & \multirow{3}{*}{$\begin{array}{l}\text { Determination } \\
\text { of the beginning } \\
\text { month }\end{array}$} & Solar & Only hisab \\
\hline & & Lunar & Rukyah and hisab \\
\hline & & Luni-solar & Rukyah and hisab \\
\hline
\end{tabular}

Apart from the three calendar reference systems, based on the complexity of the calculations used, the calendar is also divided into two:

1. Astronomical Calendar

Astronomic Calendar is a calendar based on astronomical calculations, which is arranged based on the actual movement or position of celestial bodies, whether the sun, moon or both. Hence one needs to "look at the sky" to set the date.

\footnotetext{
${ }^{47}$ Ahmad Fadholi, Ilmu Falak Dasar, (Semarang: El-Wafa, 2017), 199-200

${ }^{48} \mathrm{Al}-\mathrm{Qur}$ 'an dan Terjemahannya.., h. 283-284

${ }^{49}$ From various sources. The differences above are differences in general, especially attributed to the Gregorian calendar, hijriah and nasi'.
} 
Astronomical calendars, use the solar tropical cycle, and some use the synodic cycle of the moon, or both. The solar tropical cycle is the cycle of the sun past the vernal equinox twice in a row. Meanwhile, the lunar synodic cycle is a cycle of the same two phases of the moon in sequence. ${ }^{50}$

An example of an astronomic calendar is the Chinese calendar, it originates from the He dynasty, years 2205-1766 BC. It uses a luni-solar based calendar. In $1644 \mathrm{AD}$, the Chinese calendar used modern astronomical theory which uses the beginning of the month based on when the actual lunar conjunction occurs.

Another example is the hijri calendar, which determines the 1st by looking at the crescent moon. therefore in making the hijriah calendar using astronomical reckoning calculations that calculate the position of the sun, earth and moon, to get results about the position of the moon. This has left two problems to this day, namely regarding the agreement on the criteria for the entry of the new moon, and regarding the mathlak (date line). Therefore some hijri calendars do not dare to say that the dates listed are fixed.

Although astromatic-based calendars are more complicated, that doesn't mean they can't be calculated or predicted. Because the rotation of celestial bodies is very regular. As Allah says:

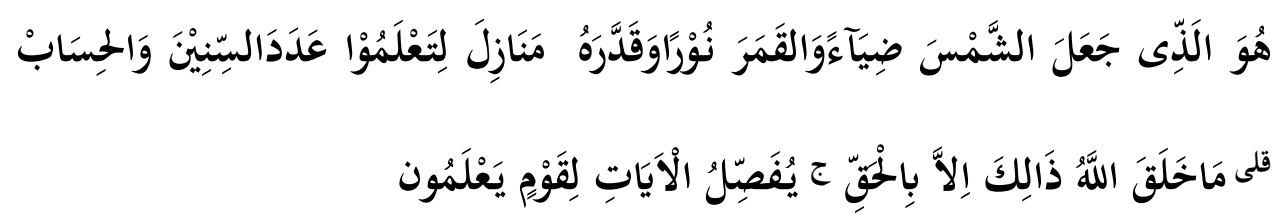

"He is the one who makes the sun shine and the moon shine and He appointed manzilah (places) for the journey of the month, so that you will know the number of years and calculations (time). Allah did not create such but with rights. He explains the signs (of His greatness) to those who know. " (Surah Yunus / 10: 5). ${ }^{51}$

The advantage of the astromatic calendar is that there is no need for corrections as in the Javanese calendar or the Gregorian calendar. Also a

\footnotetext{
${ }^{50}$ Bashori, PenanggalanIslam, 14-15

${ }^{51}$ Al-qur'an dan Terjemahannya.., h. 306
} 
calendar in accordance with the crossing of celestial bodies, therefore it becomes a calendar with a highaccuracy.

2. Arithmetic Calendar

Arithmetic Calendar is a calendar that is arranged based on mathematical / arithmetic calculations, it does not need to make astronomical observations such as observations or rukyat. This calendar can be easily calculated because it is based on arithmetic formulas ${ }^{52}$ and calculations, and or is based on rules. ${ }^{53}$

In the Arithmetic calendar, the calendar still uses the rotation of the celestial bodies approach, but uses a simple formula. The number of days in a month is determined by the number, but because the number of days in a year is not astronomical, the fractions are then collected and added 1 day in a leap year.

An example of this calendar is the Gregorian calendar, which in one cycle is equal to 4 years (1461 days), therefore every 4 years consists of 3 basitah years (365 days), and 1 leap year (366 days). Another example is the term hijriah calendar which has a 30 year cycle, or the Javanese calendar which has a cycle of 8 years, where although it is based on lunar cycles, the number of days in a month has been determined. ${ }^{54}$

The advantage of an arithmetic calendar is that it is easy to calculate when specific dates occur. Meanwhile, the weakness of the arithmetic calendar is less than perfect accuracy and the need for corrections. If there is a calendar of this type of arithmetic that is very accurate, then its accuracy decreases slowly

\footnotetext{
${ }^{52}$ Example of the Gregorian calendar

${ }^{53}$ Example of the Jewish calendar

54 Some notes regarding the hijriah calendar arithmetic, among them
}

1. This calendar is only prepared based on arithmetic calculations, not based on observations, rukyat, or criteria for the minimum sighting of the new moon.

2. It could be that there is a difference in the date of one day between this calendar system and the results of the observation of the new moon

3. This system is set the same all over the world, even though it could be two places that are very far apart, resulting in different dates.

4. The arrangement in this calendar, odd months are always 30 days, while genp month is always 29 days, except for the last month for leap years. In reality based on the observation of the new moon this is not always the case, although it is impossible for it to be 28 or 31 days. 
over time due to changes in the rotation of the earth. This limits the life of the accurate arithmetic calendar to several thousand years, after which the rules need to be modified from observations made since the invention of the calendar. $^{55}$

In view of the development of the calendar formulation, the calendar is divided into four. First, the Primitive Calendar, second, the ethnic calendar (ethnic calendar system), ${ }^{56}$ third, the calendar of the nations (the national calendar system), ${ }^{57}$ fourth, the religious calendar (regional calendar system), ${ }^{58}$ fifth, the organizational and intellectual calendar. ${ }^{59}$

Thus, the calendar issue is a scientific problem that intersects with celestial bodies in the form of the sun and moon. Mathematically, it can be predicted, but until today the discourse of the calendar, especially the astronomical hijriah calendar, which is related to the scheduling of worship rituals has never ended. This discrepancy is triggered by different interpretations of the text and the context related to the formulation of a definitive calendar. ${ }^{60}$ Therefore a meeting point is needed from opposing sides that have developed according to the capabilities and insights of ijtihad.

\section{C.2. Hijri Calendar}

The Hijri calendar is also called the Islamic calendar, is a pure lunar calendar that follows the cycle of the phases of the moon around the earth without any connection with a tropical year. ${ }^{61}$ The hijri calendar is a calendar that is used by

\footnotetext{
${ }^{55}$ Bashori, Penanggalan Islam,. 10-14

${ }^{56}$ ethnic calendar (ethnic calendar system), such as the Javanese calendar, the caka-bali calendar, the Bugis calendar, the Mayan calendar, and so on.

${ }^{57}$ Calendar of the nations (National calendar system), for example, ancient Egyptian calendar, ancient Roman calendar, Indian calendar, Turkish calendar.

58 religious calendar (regional calendar system), such as the Chinese calendar, the hijri calendar.

${ }^{59}$ Syarif, Perkembangan Perumusan Kalender, 60-119

organizational and intellectual calendars. For example the hijri calendar with the criteria of Muhammadiyah, NU Almanac, taqwim Indonesian standards.

${ }^{60}$ Butar-butar, KalenderIslam, 99

${ }^{61}$ Anisah Budiwati, Teori dan Aplikasi Ilmu Falak di Perguruan Tinggi Islam, (Yogyakarta: Buku Ajar Universitas Islam Indonesia, 2017) h. 91
} 
Muslims both in determining the date or month related to worship, as well as other important days. ${ }^{62}$

The determination of the start of the hijri month is based on the time of conjunction, which according to language is gathering. ${ }^{63}$ conjunction is when the three celestial bodies, moon, earth and sun are in one astronomical plane perpendicular to the plane of the earth's orbit (ecliptic). ${ }^{64}$ Conjongsi is the beginning of the separation process between the old and new moon phases, at the time of conjunction, the moon and the sun are at the same ecliptic point. ${ }^{65}$

The method of determining the beginning of the Hijri month is generally divided into hisab urfi / istilahi, and hisab hakiki. hisab urfi / istilahi is a calculation system that uses the average data of the moon around the earth using the calculation standards used by calculators, ${ }^{66}$ which is based on general rules of motion or the moon's journey around the earth in one synodic year, which is one period of ijtima ' / conjunction one to another that takes 29 days 12 hours 44 minutes 2.8 seconds, ${ }^{67}$ in one turn / month. The age of the month in this term reckoning always changes between 30 and 29, except for the month of dzulhijjah totaling 29 for the basitah year and 30 in the leap year. ${ }^{68}$ One cycle of this calendar is 30 years, of which 11 are leap years and 19 basithah years.

Hisab hakiki, is a calculation system based on the actual circulation of the moon and earth. According to this system, the age of the moon is not constant and irregular, but depends on the position of the new moon at the beginning of the month. Thus it may be two months in a row the age is 29 or 30 days, it may also be alternating like

\footnotetext{
${ }^{62}$ Fadholi, Ilmu Falak, 199

${ }^{63}$ Abdul Karim, Mengenal Ilmu Falak, (Semarang: Intra Pustaka Utama, 2006), 13

${ }^{64}$ Lutfi Adnan Muzamil, Studi Falak dan Trigonometri Cara Cepat dan Praktis Memahami Trigonometri dalam Ilmu Falak, (Yogyakarta: Pustaka Ilmu, 2015), 23

${ }^{65}$ Baharuddin Zainal, Ilmu Falak Teori, Praktik dan Hitungan, (Kuala Terengganu: Yayasan Islam Terengganu, 2003), 99

${ }^{66}$ Shofwan Jannah, Kalender Hijriah dan Masehi 150 Tahun : 1364-1513H (1945-2090), (Yogyakarta: UII Press, 1994), 1

${ }^{67}$ Fadholi,Ilmu Falak, 203

${ }^{68}$ There is a leap year because from the number 44 minutes 2.88 seconds per month in one year it is multiplied by 12 , then it is multiplied by 30 (one cycle), so that it amounts to 264 hours 16 minutes 48 seconds. 264 hours $=11$ days. Therefore for 30 years there are 11 leap years or for which the number of days is increased by one.
} 
hisab urfi / istilahi. In its practical area, this system uses astronomical data and the motion of the moon and earth and uses the rules of measuring the spherical triangle. ${ }^{69}$

Hisab hakiki is used by Muslims, especially as a guide in determining dates related to worship. Because it is a calendar with precise calculations and based on the location of the actual crescent, so it has a high degree of accuracy. As Allah says:

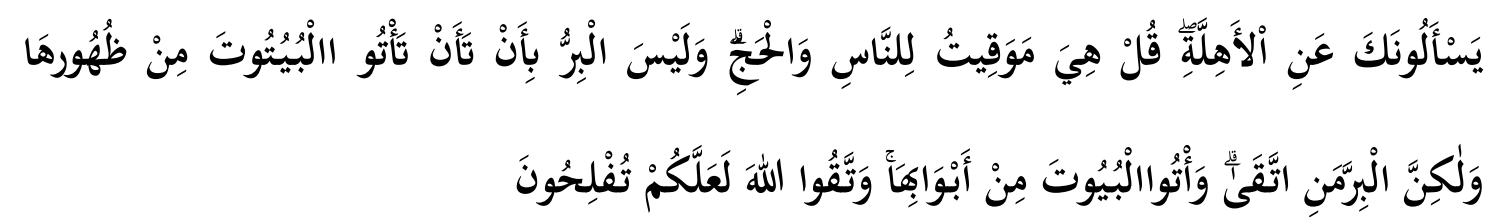

"They ask you about the crescent moon. Say: "The crescent moon is a sign of time for humans and (for worship). Hajj: and it is not the virtue of entering the houses from behind him, but the virtue of the pious person. And enter into the houses by the door; and fear Allah so that you will be lucky. " (Surah Al-Baqarah / 2: 189). ${ }^{70}$

Thus, the hijri calendar has at least an arithmetic calendar in the form of calculating terms, which was used during the time of Umar bin Khattab, which is a calendar with an established system. and an astronomical calendar in the form of essential calculations used for religious purposes. Even if there is a polemic to this day, it is something that makes sense considering the Hijri calendar is the most important astronomical calendar, and has the greatest influence in the world to this day.

\section{C.3. Javanese Calendar}

Not all tribes in the world have their own calendar. Java is one that has its own calendar, which has a pre-national calendar based on the movement of the sun, and a Javanese calendar which is based on the calculation of the moon.

The Javanese calendar was created by mpu Hubayun, in 911 BC. Then King Mahapunggung I (Ki Ajar Padang I) in 50 BC, made changes to Javanese script and literature which for the calendar was based on sangkan paraning dumadi (the origin of life). Furthermore, in 78 AD, Prabu Ajisaka made changes by absorbing elements from India, so that a new Javanese year began, the 1st of Badrawana, the year of Sri Harsa,

\footnotetext{
${ }^{69}$ Susiknan Azhari, Ilmu Falak Teori dan Praktek, (Yogyakarta: Azuardi, 2001), 96

${ }^{70}$ Al-Qur'an dan Terjemahannya.., h. 46
} 
Windu Kuntara or the 1 st of the month 1 year 1 windu 1 , the day of radiant love or ahad kliwon. ${ }^{71}$

That is why, the Javanese calendar is said to have originated from a Hindu style inspired by the Indian calendar. The Javanese calendar in several versions is stated to have been used since June 21, $78 \mathrm{AD},{ }^{72}$ March 14, $78 \mathrm{AD} .{ }^{73}$ the battle against the Saka, but there are also those who claim that the Saka won in the battle. ${ }^{74}$ At the beginning of this calendar, some say it began when King Syaliwahono (aji saka) ${ }^{75}$ or king Sariwahana Ajisaka ascended the throne in India. ${ }^{76}$ Aji Saka is a mythological figure who created the Javanese alphabet; ha, na, ca, ra, ka. ${ }^{77}$

At that time, the Javanese calendar was based on the solar calendar, because before the Hindus came, the Javanese people already had their own calendar known as petangan jawi, which is the calculation of the prey structure with a series of various tweets such as wuku, peringkelan, padean, padangan, and so on.

The saka calendar or Javanese calendar at that time, occurred during the Minasamkranti (sun in the constellation Pisces) early spring. It is divided into one year which has 12 months, among them:
a) Srawana (12 July - 12 August) 32 days
b) Bhadra (13 August - 10 September) 29 Days
c) Asuji (11 September - 11 October) 31 Days
d) Kartika (12 October - 10 November) 30 days

\footnotetext{
${ }^{71}$ Sejarah Kalender jawa, Retrieved February 1, 2020 www.infobudaya.net.

${ }^{72}$ Ruswa darsono, penanggalan Islam Tinjauan Sistem, Fiqih dan Hisab Penanggalan,(Yogyakara Labda Press, tt), 91

${ }^{73}$ Purwadi dan Siti Maziyah, Horoskop Jawa,(Yogyakarta; Media Abadi, 2007),1

${ }^{74}$ Hambali, Almanak Sepanjang Masa, 16

${ }^{75}$ A. Izzuddin, Sistem Penanggalan, (Semarang: Cv. Karya Abadi, 2015), 95

${ }^{76}$ Therefore many claim that Ajisaka is Hindustani / Indian. However, there are those who claim that King Ajisaka was a Javanese, with several assumptions, including

a. The name Ajisaka (aji \& saka) comes from the ancient Javanese language which means rraja yang aji, namely a king who understands and has spiritual abilities. Raja Ajisaka also has the names Prabu Sri Mahapunggung III, ki AjarPadang III, Prabu jaka angkala, Widayaka, Sindula, which are Javanese names. The performance is said to be in the Eternal Flame of Mrapen-Grobogan village.

b. The heirloom of Ajisaka was entrusted with a keris-shaped assistant. Keris is Javanese culture, not Indian. c. There are 4 loyal servants of King Ajisaka with names from the kawi language, namely Dura (which means natural elements in the form of water), Sambadha (which means natural elements in the form of fire), Duga (which means natural elements in the form of soil), and Prayuga (which means natural elements in the form of water), in the form of wind).

${ }^{77}$ Purwadi, Horoskop Jawa, 1
} 
e) Posya (11 November - 12 December) 32 days

f) Margasira (13 December - 10 January) 29 days

g) Magha (11 January-11 February) 32 Days

h) Phaluna (12 February - 11 March) 29 days.

i) Cetra (12 March - 11 April) 31 Days

j) Wasekha (12 April - 11 May) 30 Days

k) Jyesta (12 May - 12 June) 32 Days

1) Ashada (13 June -11 July) 29 Days

Then, Javanese calendar experienced assimilation in the XVI century, 1625 AD, Sri Sultan Muhammad, or known as Sultan Agung Anyokrokusumo issued a decree to date the Saka. The change occurred on Friday legi, 1 Sura in alif 1555 or 1 Muharram 1043 Hijriah, which coincided on July 8, 1633 AD. Therefore, the Javanese calendar has 2 periods, the Javanese-Hindu period, which is calculated based on the movement of the sun, and the Javanese-Islamic period, whose movement is based on the movement of the moon.

This change has become a kind of political compromise to embrace diverse people, between Islam and Kejawen. Because at that time there were 3 elements of the dominant cultural calendar, Kabudhan (solar), Hindi (solar), and Islam / hijriyah (Lunar), and Julian / Roman (solar). In addition, the western region / around Sunda Kelapa has been controlled by a foreign nation, the Dutch. So to strengthen unity against foreign nations, the calendar was unified using one name, the Javanese calendar.

Therefore, in this calendar, the year follows the saka year, which is 1555 , while the system is changed based on the moon, as well as the names of the months:
a) Suro 30 days 30
b) Sapar 29 days 59
c) Mulud 30 days 89
d) Bakda mulud 29 days 118
e) Jumadil early 30 days 148
f) Jumadil Akhir 29 days 177
g) Rejeb 30 days 207
h) Ruwah 29 days 236 
i) Poso 30 days 266

j) Sawal 29 days 296

k) Sela 30 days 325

1) Besar 29/30 days $354 / 355$

The reforms made by Sultan Agung and his team emphasized the calendar as a timeline, but the other components of the Javanese calendar were not deleted. So that this change does not cause rejection of Islam, it also accommodates the voice of Islam which prohibits prediction and witchcraft. Besides changing the name of the day, it is also to eliminate the mention of the gods, so that it is avoided from polytheism, ${ }^{78}$ as well as the name of the month which is a combination name between Javanese, Sanskrit and Arabic, so that it becomes the name of the Javanese month which has a more Islamic nuance and pasaran is maintained because it does not contradict religious beliefs. Thus a unique 'marriage' calendar is created between religion and culture, between Islam and Kejawen, but there is an element of the Julian calendar, because it has a relatively fixed calculation system (hisab urfi).

\section{C.4. Units in Calendar}

1) Year

As the review above, that the hijri calendar was established during the reign of Umar bin Khattab, in the 17th year of Hijriah, and uses the reference for the first year when the Prophet's hijrah. This calendar continues to experience progress in understanding progress. For example, when Abu Ja'far al-mansur ordered the translation of the Sindihind book, up to the time of Fathimiyah's reign, the determination of the beginning of the month was based on astronomical calculations by General Jauhar after completing the founding of the city of Cairo in $359 \mathrm{H}$ or $969 \mathrm{AD}^{79}$

Whereas in the Javanese calendar, the changes made by sultan agung were related to the hijriyah calendar calculation system, while the number of years followed the Saka year. Thus, the number of Javanese years is 512

\footnotetext{
${ }^{78}$ Darsono, Penanggalan Islam,.., 92

${ }^{79}$ Maskhufa, Ilmu Falaq, (Jakarta: Gp Press, 2009), 160-161
} 
different from the figures for the hijriyah years. For example, the beginning of the Hijri month falls in September, Hijri year in 1441 Hijriyah, Javanese year in $1953(1953-1441=512)$. The decision of the great sultan was approved and followed by the sultan Abul Mafakhir Mahmud Abdulkadir (1956-1651) from Banten. And from then on, all of Java used this Islamic Javanese calendar. ${ }^{80}$

2) Months

In the hijri calendar, when Islam came, Muslims used the luni-solar calendar which later changed to the lunar calendar. Until now, at least the names of the months in the Hijri calendar have changed 4 times, including: ${ }^{81}$

\begin{tabular}{ccccc}
\hline \multirow{2}{*}{ NO } & \multicolumn{4}{c}{ Nama-Nama Bulan Kalender Hijriah } \\
\cline { 2 - 5 } & I & II & III & IV \\
\hline 1 & Naiq & Mujab & Al-Mu'tamar & Muharram \\
\hline 2 & Thaqil & Mujar & Najir & Safar \\
\hline 3 & Taliq & Murad & Khawan & Rabiulawal \\
\hline 4 & Najir & Mulzam & Zubar & Rabiulahir \\
\hline 5 & Samah & Masdar & Hantam & Jumadilawal \\
\hline 6 & Amnah & Hubar & Zubar & Jumadilahir \\
\hline 7 & Akhlak & Hubal & Al-Asam & Rajab \\
\hline 8 & Kasa' & Muha' & 'Adil & Sya'ban \\
\hline 9 & Zahir & Dimar & Nafiq & Ramadhan \\
\hline 10 & Barf & Dabir & Waghil & Syawwal \\
\hline 11 & Hafr & Hifal & Hawagh & Zulkaidah \\
\hline 12 & Na's & Mutbal & Burak & Zulhijjah \\
\hline
\end{tabular}

The name of the month from the Javanese calendar is an adoption of the Islamic calendar, but also with adjustments to the Javanese tongue and Islamic culture in Java. For example, the month of Muharram is replaced with the month of Suro, because there is a commemoration of Asy-Syura in it. The month of Rabiul Awal is changed to the month of Mulud, because there is a date of birth of the Prophet in it, the month of Sya'ban is replaced with the month of Ruwah, because the month of Sya'ban is before Ramadlan, which is at that time in Javanese custom there is a prayer to send the spirit ancestors who have died, Ruwah reminded of the word spirit. Ramadlan was replaced with Poso, because it is a month for fasting. Dzulqa'dah is changed to the

\footnotetext{
${ }^{80}$ Maskhufa, Ilmu Falaq, 93

${ }^{81}$ Sakirman, Ilmu Falak Spektrum Pemikiran Mohammad Ilyas,(Yogyakarta: Idea Press, 2015), 40
} 
month of Selo, because it is crushed by two holidays, namely Eid Al-Fitr during Syawal and Eid Al-Adha during Dzulhijjah, Selo means between them and Dzulhijjah is replaced with Big, because there is Eid al-Adha, which is believed to be a bigger day than Eid, and in the month of Dzulhijjah there are recommendations to slaughter sacrificial animals, hajj, and there are tasyriq days.

Here are the names of the Javanese months and their comparisons

\begin{tabular}{cccc}
\hline No & $\begin{array}{c}\text { Saka Javanese } \\
\text { Month }\end{array}$ & Java Month Currently & Hijri Month \\
\hline 1 & Srawana & Sura & Muharram \\
\hline 2 & Bhadra & Sapar & Shafar \\
\hline 3 & Asuji & Mulud & Rabi'ul Awal \\
\hline 4 & Kartika & Bakda Mulud & Rabiul Akhir \\
\hline 5 & Posya & Jumadil Awal & Jumadil Awal \\
\hline 6 & Margasira & Jumadil Akhir & Jumadil Akhir \\
\hline 7 & Magha & Rejeb & Rajab \\
\hline 8 & Phaluna & Ruwah & Sya'ban \\
\hline 9 & Cetra & Poso & Ramadhan \\
\hline 10 & Wasekha & Sawal & Syawal \\
\hline 11 & Jyesta & Selo & Dzuqa'dah \\
\hline 12 & Ashada & Besar & Dzulhijjah \\
\hline
\end{tabular}

3) Days or Saptawara

Day is the time or time from sunset to sunset again. ${ }^{82}$ It is said to be a day if using one 24-hour unit of time, or a day combining day and night. ${ }^{83}$ Change of day / date in the Gregorian calendar, usually the date starts at 00.00 or 12 o'clock in the evening. On the qamariyah calendar, including the hijri calendar, the day begins shortly after sunset. ${ }^{84}$ Or at maghrib, because seeing the rising of the moon is usually done and only seen after sunset. Meanwhile,

\footnotetext{
${ }^{82}$ Abdul Karim, Mengenal Ilmu Falak,3

${ }^{83}$ Mohammad Ilyas, Sistem Kalender Islam dari Perspektif Astronomi, (Selangor: Percetakan dewan Bahasa dan Pustaka, 1997), 17

${ }^{84}$ Shofiyullah, Metode Hisab Sullam Al-Nayyirain dalam Perspektif Astronomi, (Disertasi, UIN Walisongo Semarang, 2018), h. 37
} 
in the month of Java, the day begins at the time of after Ashar, ${ }^{85}$ but now there are 2 opinions, which state bakda Asr and those who declare bakda maghrib.

Days are also called saptawara, because the day counting system consists of 7 days, and each of these days has a neptu dina (day value). ${ }^{86}$ The name of the day unit from the first to the seventh day is an adoption of the hijriyah calendar adapted to the Javanese tongue. Here is the name of the day and the comparison

\begin{tabular}{llllll}
\hline \multirow{2}{*}{ No } & \multicolumn{2}{c}{ Saka Calendar } & \multicolumn{2}{c}{$\begin{array}{c}\text { Hijri } \\
\text { Calendar }\end{array}$} & \multicolumn{2}{c}{ Arti } & & \multicolumn{2}{c}{ Nava Calendar } \\
\cline { 2 - 2 } 1 & $\begin{array}{l}\text { Radite } \\
\text { raditya }\end{array}$ & (Dewa) Matahari & Al-Ahad & Ngahad & 5 \\
\hline 2 & Soma & (Dewa) Bulan & Al-Isnayni & Senen & 4 \\
\hline 3 & Anggara & (Dewa) Api & As-Tsulaatsa & Slasa & 3 \\
\hline 4 & Budddha & (Dewa) Bumi & Al-Arbi'a & Rebo & 7 \\
\hline 5 & $\begin{array}{l}\text { Respati } / \\
\text { Wrahaspati }\end{array}$ & (Dewa) Gelap & Al-Khamis & Kemis & 8 \\
\hline 6 & Sukra & (Dewa) Air & Al-Jumu'ah & Jemuah & 6 \\
\hline 7 & Saniskara & (Dewa) Angin & As-Sabt & Setu & 9 \\
\hline
\end{tabular}

4) Pancawara or Market

In the Javanese calendar, there is the term Pancawara which means prayer for people who give birth so that it is smooth, in another meaning it means prayer, etang (calculation), etang gangsal (five calculations). ${ }^{87}$ Pancawara or pasaran, the circulation of the five international pasaran days. ${ }^{88}$ It is used together with the name of the day, and the cycle runs separately which will repeat itself in 35 days. So that after 35 days it is called selapan, the day and the market will repeat itself back to normal. ${ }^{89}$ For example Tuesday Legi, then 36 days later it will fall on Tuesday Legi again.

${ }^{85}$ Djanudji, Penanggalan Jawa 120 tahun Kurup Asapon 24 Maret 1936-25 Agustus 2053,(Semarang: Dahara prize, 2013), 30

\footnotetext{
${ }^{86}$ Azhari, Ensiklopedi Hisab Rukyat, 189

${ }^{87}$ Djanudji, Penanggalan Jawa, hal 30

${ }^{88}$ Susiknan Azhari, Ensiklopedi Hisab Rukyat, 167

${ }^{89}$ Darsono, Penanggalan Jawa, 96
} 
Pancawara was originally created by Empu Sangkala, in the 1st year of saka. ${ }^{90}$ Then in 288 Rishi Raddhi or Sang Hyang Prawa / Sang Hyang Surya also composed five days. ${ }^{91}$ Also writing a period of 12 called the pali period or the prawa period and making up the names of the stars through which the sun and moon passed is called dyamasastra fiber.

The Pancawara by Raddhi's receipt was then adjusted to the Pancawara by Empu Sangkala and adjusted to the way of worshiping him.

\begin{tabular}{|c|c|c|c|c|c|c|}
\hline \multirow{2}{*}{ No } & \multicolumn{3}{|c|}{ Empu Sengkala } & \multirow{2}{*}{ Place } & \multirow{2}{*}{$\begin{array}{c}\text { Resi } \\
\text { Raddhi }\end{array}$} & \multirow{2}{*}{$\begin{array}{c}\text { Nep- } \\
\text { tu }\end{array}$} \\
\hline & Day Name & Other Name & Color & & & \\
\hline 1 & Hari Sri & Pethakan & White & East & Legi & 5 \\
\hline 2 & Hari Brah-ma & Abritan & Red & South & Pahing & 9 \\
\hline 3 & Hari Kala & Jenean & Yellow & West & Pon & 7 \\
\hline 4 & Hari Wis-nu & Ceme-ngan & Black & North & Wage & 4 \\
\hline 5 & Hari Guru & Manca-warna & Five colors & Central & Kliwon & 8 \\
\hline
\end{tabular}

The longer, Pancawara Kadewatan was less popular than the Pancawara written by the Raddhi sage as it is used today, but the people who followed the way of worship according to Empu Sangkala were increasing. So that the time to worship is used for a long time to bring the produce in the area to be exchanged for other items from other participants to make ends meet. Finally, this place is called the market, the day used for gathering is called pasaran. The place facing the time of worship on each of these days is called tempat sangatnya pasaran.

Tempat sangatnya pasaran is usually combined with tempat sangatnya hari, and it is used to find a place or direction to start something or other purposes. But by paying attention, such as the year dragon, the sasi dragon, the place of wuku, and so on. ${ }^{92}$

5) Calendar cycle

In the hijri calendar, with hisab ufri/istilahi system, in one cycle there are 30 hijri calendar years, with 11 long (leap) years 355 days, which occur in

\footnotetext{
${ }^{90}$ The origin of Pancawara is a story from Sengkala or Saka Empu Sengkala, when he was meditating, a white light came one night which was actually a Goddess from Heaven named Batari Sridan giving lessons about the science of compassion and how to do asmaragama, asmaranada, asmaraturida and asaranala.

${ }^{91}$ Legi, Pahing, Pon, Wage, dan Kliwon.

${ }^{92}$ Djanudji, Penanggalan Jawa, 35
} 
years $2,5,7,10,13,16,18,20,24,26$, and 29. And there are 19 short years (basithah), 354 days, in years 1, 3, 4, 6, 8, 9, 11, 12, 14, 15, 17, 19, 21, 22, 23, $25,27,28$ and $30 .{ }^{93}$

Meanwhile, in the Javanese calendar, the years are grouped into eight years called windu, which is a system of calculating time with a cycle of eight years in the Javanese calendar. During one windu there are three long years called wuntu (355 days old) and a short year called wastu (354 days old). ${ }^{94}$ The years of the windu are named after the sound of the Arabic letter which has been adjusted..$^{95}$ Eight years with the following names:

\begin{tabular}{lll}
\hline No & Year Name & Arabic Letter \\
\hline 1 & Alip & Alif \\
\hline 2 & Ehe & Ha' \\
\hline 3 & Jimawal & Jim (awal) \\
\hline 4 & Ze & Za \\
\hline 5 & Dal & Dal \\
\hline 6 & Be & Ba \\
\hline 7 & Wawu & Waw \\
\hline 8 & Jimakir & Jim (ahir) \\
\hline
\end{tabular}

In one windu it consists of 8 years provided that, if the first year (alif) falls on Tuesday (1), then the second year (ehe) falls on Saturday (5), the third year (jimawal) on Thursday (3), then the fourth year (ze) falls on Monday (7), while the fifth year (dal) falls on Friday (4), then the sixth year (be) on Wednesday (2), while the seventh year (wawu) on Sunday (6) and the eighth year (jimakir) falls on Thursday (3). After that it comes back again in the first

${ }^{93}$ Hambali, Almanak Sepanjang Masa,. 63
${ }^{94}$ Azhari, Ensiklopedi Hisab Rukyat, 238
${ }^{95}$ The Arabic name, which is the sequence number referred to in the alphabet, looks as follows:
\begin{tabular}{|l|l|l|l|l|l|l|l|}
\hline Unit & Dozens & \multicolumn{1}{l}{ Hundreds } & \multicolumn{1}{l}{ Thousand } \\
\hline 1 & Alif & 10 & Ya' & 100 & Qaf & 1000 & Ghain \\
\hline 2 & Ba' & 20 & Kaf & 200 & Ra' & 2000 & Ba' + ghain \\
\hline 3 & Jim & 30 & Lam & 300 & Sya & 3000 & Jim + ghain \\
\hline 4 & Dal & 40 & Mim & 400 & Ta' & 4000 & Dal + ghain \\
\hline 5 & Ha' & 50 & Nun & 500 & Tsa & 5000 & Ha' + ghain \\
\hline 6 & Wawu & 60 & Sin & 600 & Kho & 6000 & Wawu + ghain \\
\hline 7 & Za' & 70 & 'ain & 700 & Dza & 7000 & Za' + ghain \\
\hline 8 & cha' & 80 & Fa' & 800 & Dhod & 8000 & Cha + ghain \\
\hline 9 & Tha' & 90 & Shat & 900 & Dha & 9000 & Tha + ghain \\
\hline
\end{tabular}

Hambali, Almanak Sepanjang Masa, 62 
year (alif), so on, until about 120 years or 15 windu, after which there will be adjustments and it is said to replace the brackets.

In the 8 year / sewindu cycle, there are 3 long / leap / wuntu years, totaling 255 days. and 4 short years / basithah / wastu, totaling 254 days. Thus, one windu is equal to $(255 \times 3)+(254 \times 4)=2,835$ days. So that in one cycle of 30 hijri calendar years there is an excess of $1 / 4$ longer days on the Javanese calendar. Therefore, in $4 \times 30$ years $=120$ years, the Javanese calendar will be one day excess compared to the term Hijriyah calendar. So the Javanese calendar was adjusted to the hijriyah calendar within 120 years, which is called the kurup. ${ }^{96}$

6) Wuku and Pakuwon

The calculation of the pakuwon time is a time calculation system which is seven days long. The Javanese calendar consists of 30 wuku cycles, each of which consists of 7 days starting from Sunday and ending with Saturday. So, in one pakuwon has a cycle of 30 wuku times 7 days, which means 210 days. The first wuku (wuku sinta) starts from Sunday pahing to Saturday pon, while the last wuku (wuku watugunung), starts from Sunday kliwon to Saturday legi. ${ }^{97}$

Pakuwon was inspired by the legend of King Watugunung and his family related to penance for a sense of $\sin$. The wuku consists of: wuku sinta, wuku landep, wuku wurir, wuku kurantil, wuku tolu, wuku gambreng, wuku warigalit, wuku wariagung, wuku julungwangi, breech wuku, wuku rolls, wuku kunigan, wuku langkir, wuku mandangsia, wukujulungpuut, wuku pahang, wuku kuruwelut, wuku marakeh, wuku tambir, wuku mandangkungkungan, maktal wuku, wuku wuye, wuku manahil, prangbangkat wuku, wuku bala, wuku wugu, puppet wuku, kalawu wuku, dukut wuku and watugunung wuku.

7) Pranatamangsa

Javanese society has a seasonal calendar, it is called pranatamangsa. pranatamangsa is a division of the period of one year into 12 periods. The period differs from the month, including the number of days. Pranatamangsa is

\footnotetext{
${ }^{96}$ Djanudji, Penanggalan Jawa, 99

${ }^{97}$ Purwadi, Horoskop Jawa, 16
} 
the stipulation of the season, which is a kind of calendar which is mainly associated with agricultural and fishery business activities. Pranatamangsa is based on solar circulation and its cycle is 365 days or 366 days a year and contains various aspects of phenology (animal and animal behavior) and other natural phenomena which are used as guidelines in agricultural activities and disaster management. ${ }^{98}$

Pranatamangsa was published in the book Centini by Paku Buwono, which was compiled between 1820-1833. by Sri Susuhan Paku Buwana VII in Surakarta on 22 June $1856 .{ }^{99}$ The start of the season in Java is with the gauze season or the first season, starting on the date of its inauguration as a milestone. ${ }^{100}$

The presence of pranatamangsa made Javanese agriculture developed rapidly. Besides that, it shows the richness of culture and ecological treasures which are called earth spirituality. As well as encouraging farmers and fishermen to get to know the natural characters in each place, the Panatamangsa divides one year ino twelve mongso or period. ${ }^{101}$

C.5. Correlation between the Javanese Calendar and the Hijri Calendar

As explained above, that the Javanese calendar, which was modified by the Sultan Agung, adopted the hijri calendar. Because it is based on the cycles of the moon. The Hijri calendar uses hisab hakiki which is a more accurate reference to the movement of the moon around the earth, while the Javanese calendar uses hisab urfi with constant calculations with some corrections. ${ }^{102}$

${ }^{98}$ Anton Rimanang, Pranatamangsa Astrologi Jawa Kuno, ed. Andreas Troi Prasetya (Yogyakarta: Kepel Press, 2016), 11.

${ }^{99}$ Sindhunata, Pranata Mangsa (Jakarta: KPG (Kepustakaan Populer Gramedia), 2011), 2.

${ }^{100}$ The pranatamangsa calendar has a varying age, between 23 to 43 days, this is because the basis used for the prey is physical and biological phenomena. June 22 is the first day of the sun's shift from the equinox, thus affecting the meteorological elements of a region.

${ }^{101}$ Rimanang, Pranatamangsa, 22-45

The months in Pranatamangsa are Masa: Kasa-Kartika, 22 June -1 August; Karo-Pusa. 2 August - 25 August; Katelu-manggasri, 25 August-12 September; Kapat-Sitra, 12 September-13 October; Kalima-Manggakala, 14 October-9 November; Kanem-Naja, 10 November-22 December; Kapitu-Palguna, 23 December-3 February; Kawolu-Wisaka, 4 February-30 February; Kasanga-Jita, March 1-March 25; Kasapuluh Srawana, 26 March-18 April; Dhesta-Padrawana, 19 April-11 May; Saddha-Asudji, 12 May-21 June.

${ }^{102}$ Sofwan Jannah, Kalender Hijriah-Masehi 150 Tahun: 1364-1513 H (1945-2090M),(Yogyakarta: UII Press, 1994), 1

Al-Hilal: Journal of Islamic Astronomy, Vol. 2, No. 2, Tahun 2020

p-ISSN : 2775-1236 ; e-ISSN : 2775-2119 
The results of calculations using hisab urfi basically cannot be used to guide mahdhah worship activities, but for daily use, such as using the calendar is very practical and relatively easy. In addition, hisab urfi can be used as a guide for the preparation of preliminary data, in the implementation of computation of hisab hakiki, and can be used as a guideline for commemoration of Islamic holidays, and others.

At least the relationship between the Javanese calendar and the hijri calendar is seen from several aspects:

a) Both are based on the circulation of the month. The hijri calendar has a higher level of accuracy, because it purely uses the visibility of the new moon. That's why the Javanese calendar can correct by looking at the hijri calendar

b) The change of the Javanese calendar from the Saka calendar to a month-based calendar, inspired by the Hijri calendar

c) The Javanese calendar was originally intended to facilitate worship. So, the Hijri calendar is more attached than any calendar including other month-based calendars.

\section{C.6. Java-Aboge Calendar Concept}

The aboge calendar is a Javanese calendar, but it uses aboge kurup. Or the Javanese calendar whose determination is based on the standard that every year alip holidays will fall on the pasaran wage. ${ }^{103}$ Even though the Javanese kurup calendar is not in the Aboge kurup, but the asapon kurup. As explained above, the Javanese calendar experienced major changes during the reign of Sultan Agung from a solar calendar to a lunar calendar, but it did not leave Javanese elements.

Although it is based on the month, it is not based on the actual circulation of the month, but estimates. Because of that there is a consequence of a quarter-day difference in 30 years. Therefore, if there is no correction, the longer the Javanese calendar and the hijriyah calendar will have more differences as a reference calendar.

In the Javanese calendar, one cycle means one windu, that is, 8 years, or 2835 days. Whereas in the hijriyah calendar with the termi system, in one cycle there are 30 hijri calendar years. Thus, in 30 hijri calendar years there are $(11$ x 355 days $)+(19 \times 354$

${ }^{103}$ Azhari, Ensiklopedi Hisab Rukyat, hal. 7 
days $)=10,631$ days. In 120 years, there are 42,524 days (that is, 10,631 days in a 30-year cycle, times 4). Whereas in the Javanese calendar, there are 2835 days in one cycle, so in 120 years there are 42,525 days (2,835 days in an 8 year cycle, multiplied by 15$)$.

From this calculation, it can be seen that the Javanese calendar in 120 years amounts to one more day than the hijri year. Therefore, every 120 years, corrections are made by advancing the day or subtracting one day, namely on the 29th of the year of the jimakir year, on the 15th windu. And this is what is then called the change of kurup.

In the Javanese calendar, until 1953 Java or 2020 AD, there have been 4 changes of kurup:

1) Jamngiyah Kurup

Since the years 1555-1626 Java, or 1043-1114 AD. Namely 1 suro year alif on Friday legi. Lasted for 72 years. With the following information;

\begin{tabular}{cccc}
\hline No & Years & Days & Years \\
\hline 1 & Alif & FridayLegi & $1555,1563,1571,1579,1587,1595,1603$, \\
& & & 1611,1619 \\
\hline 2 & Ehe & Tuesday Kliwon & $\begin{array}{c}1556,1564,1572,1580,1588,1596,1604, \\
1612,1620\end{array}$ \\
& & & $157,1565,1573,1581,1589,1597,1605$, \\
13 & Jimawal & Sunday Kliwon & 161,1621 \\
\hline 4 & Ze & Thursday Wage & $1558,1566,1574,1582,1590,1598,1606$, \\
& & & 1614,1622 \\
\hline 5 & Dal & Monday Wage & $1559,1567,1575,1583,1591,1599,1607$, \\
& & & 1615,1623 \\
\hline 6 & Be & Saturday Pon & $1560,1568,1576,1584,1592,1560,1608$, \\
& & & 1616,1624 \\
\hline 7 & Wawu & WednesdayPahing & $1561,1569,1577,1585,1593,1561,1609$, \\
& & & 1617,1625 \\
\hline 8 & Jimakir & Sunday Legi & $1562,1570,1578,1586,1594,1562,1610$, \\
& & & 1618,1626 \\
\hline
\end{tabular}

2) Amiswon Kurup

Since the years 1627-1746 Java, or 1114-1234 AD. 1 suro alif year on Thursday Kliwon. Lasted for 120 years. With the following information;

\begin{tabular}{cccc}
\hline No & Years & Days & Years \\
\hline 1 & Alif & Thursday & $1627,1635,1643,1651,1659,1667,1675,1683$, \\
& & Kliwon & $1691,1699,1707,1715,1723,1731,1739$. \\
\hline 2 & Ehe & Monday & $1628,1636,1644,1652,1660,1668,1676,1684$, \\
& & wage & $1692,1700,1708,1716,1724,1732,1740$. \\
\hline
\end{tabular}




\begin{tabular}{cccc}
\hline 3 & Jimawal & $\begin{array}{c}\text { Saturday } \\
\text { wage }\end{array}$ & $\begin{array}{c}1629,1637,1645,1653,1661,1669,1677,1685, \\
1693,1701,1709,1717,1725,1733,1741 .\end{array}$ \\
\hline 4 & Ze & Wednesday & $1630,1638,1646,1654,1662,1670,1678,1686$, \\
& & Pon & $1694,1702,1710,1718,1726,1734,1742$. \\
\hline 5 & Dal & Sunday pon & $1631,1639,1647,1655,1663,1670,1678,1687$, \\
& & & $1695,1703,1711,1719,1727,1735,1743$. \\
\hline 6 & Be & Friday & $1632,1640,1648,1656,1664,1671,1679,1688$, \\
& & Pahing & $1696,1704,1712,1720,1728,1736,1744$. \\
\hline 7 & Wawu & Tuesday & $1633,1641,1649,1657,1665,1672,1680,1689$, \\
& & Legi & $1697,1705,1713,1721,1729,1737,1745$. \\
\hline 8 & Jimakir & Saturday & $1634,1642,1650,1658,1666,1673,1681,1690$, \\
& & Kliwon & $1698,1706,1714,1722,1730,1738,1746$. \\
\hline
\end{tabular}

3) Aboge Kurup

Since the years 1747-1866 Java, or 1235-1354 AD. 1 suro year alif, on wednesday wage. Lasted for 120 years. With the following information;

\begin{tabular}{llll}
\hline No & Years & Days & Years \\
\hline 1 & Alif & Wednesday & $1747,1755,1763,1771,1779,1787,1795,1803$, \\
& & Wage & $1811,1819,1827,1835,1843,1851,1859$ \\
\hline 2 & Ehe & Sunday Pon & $1748,1756,1764,1772,1780,1788,1796,1804$, \\
& & & $1812,1820,1828,1836,1844,1852,1860$ \\
\hline 3 & \multirow{2}{*}{ Jimawal } & Friday Pon & $1749,1757,1765,1773,1781,1789,1797,1805$, \\
& & & $1813,1821,1829,1837,1845,1853,1861$. \\
\hline 4 & Ze & Tuesday & $1750,1758,1766,1774,1782,1790,1798,1806$, \\
& & Pahing & $1814,1822,1830,1838,1846,1854,1862$. \\
\hline 5 & Dal & Saturday legi & $1751,1760,1767,1775,1783,1791,1799,1807$, \\
& & & $1815,1823,1831,1839,1847,1855,1863$. \\
\hline 6 & Be & Thursday & $1752,1761,1768,1776,1784,1792,1780,1808$, \\
& & Legi & $1816,1824,1832,1840,1848,1856,1864$. \\
\hline 7 & Wawu & Monday & $1753,1762,1769,1777,1785,1793,1781,1809$, \\
& & Kliwon & $1817,1825,1833,1841,1849,1857,1865$. \\
\hline 8 & Jimakir & Friday Legi & $1754,1763,1770,1778,1786,1794,1782,1810$, \\
& & & $1818,1826,1834,1842,1850,1858,1866$. \\
\hline
\end{tabular}

4) Asapon Kurup

Since 1867-1986 Java, or 1354-1474 AD. 1 suro year alif on Tuesday Pon. Lasted for 120 years. With the following information;

\begin{tabular}{llll}
\hline No & Years & Days & Years \\
\hline 1 & Alif & Tuesday Pon & $1867,1875,1883,1891,1899,1907,1915,1923$, \\
& & & $1931,1939,1947,1955,1963,1971,1979$. \\
\hline 2 & \multirow{2}{*}{ Ehe } & Saturday & $1868,1876,1884,1892,1900,1908,1916,1924$, \\
& & Pahing & $1932,1940,1948,1956,1964,1972,1980$. \\
\hline
\end{tabular}




\begin{tabular}{llll}
\hline 3 & Jimawal & Thursday & $1869,1877,1885,1893,1901,1909,1917,1925$, \\
& & Pahing & $1933,1941,1949,1957,1965,1973,1981$. \\
\hline 4 & \multirow{2}{*}{ Ze } & Monday Legi & $1870,1878,1886,1894,1902,1910,1918,1926$, \\
& & $1934,1942,1950,1958,1966,1974,1982$. \\
\hline 5 & \multirow{2}{*}{ Dal } & Friday & $1871,1879,1887,1895,1903,1911,1919,1927$, \\
& & Kliwon & $1935,1943,1951,1959,1967,1975,1983$. \\
\hline 6 & \multirow{2}{*}{ Be } & Wednesday & $1872,1880,1888,1896,1904,1912,1920,1928$, \\
& & Kliwon & $1936,1944,1952,1960,1968,1976,1984$. \\
\hline 7 & \multirow{2}{*}{ Wawu } & Sunday Wage & $1873,1881,1889,1897,1905,1913,1921,1929$, \\
& & & $1937,1945,1953,1961,1969,1977,1985$. \\
\hline 8 & \multirow{2}{*}{ Jimakir } & Thursday & $1874,1882,1890,1898,1906,1914,1922,1930$, \\
& & Pon & $1938,1946,1954,1962,1970,1978,1986$. \\
\hline
\end{tabular}

5) What is coming, Kurup Isnaniyah.

Since 1987-2106 Java, or 1475-1595 AD. 1 suro year alif, on Monday Pahing. Lasted for 120 years. With the following information;

\begin{tabular}{llll}
\hline No & Years & Days & Years \\
\hline 1 & Alif & Monday & $1987,1995,2003,2011,2019,2027,2035,2043$, \\
& & Pahing & $2051,2059,2067,2075,2083,2091,2099$ \\
\hline 2 & Ehe & Friday Legi & $\begin{array}{l}1988,1996,2004,2012,2020,2028,2036,2044, \\
2052,2060,2068,2076,2084,2092,2100\end{array}$ \\
& & & $1989,1997,2005,2013,2021,2029,2037,2045$, \\
\hline 3 & \multirow{2}{*}{ Jimawal } & Wednesday & $2053,2061,2069,2077,2085,2093,2101$ \\
\hline \multirow{2}{*}{ Ze } & & Legi & $1990,1998,2006,2014,2022,2030,2038,2046$, \\
& & Kliwon & $2054,2062,2070,2078,2086,2094,2102$ \\
\hline 5 & \multirow{2}{*}{ Dal } & Thursday & $1991,1999,2007,2015,2023,2031,2039,2047$, \\
& & Wage & $2055,2063,2071,2079,2087,2095,2103$ \\
\hline 6 & \multirow{2}{*}{ Be } & Tuesday & $1992,2000,2008,2016,2024,2032,2040,2048$, \\
& & Wage & $2056,2064,2072,2080,2088,2096,2104$ \\
\hline 7 & \multirow{2}{*}{ Wawu } & Saturday Pon & $1993,2001,2009,2017,2025,2033,2041,2049$, \\
& & & $2057,2065,2073,2081,2089,2097,2105$ \\
\hline 8 & Jimakir & Wednesday & $1994,2002,2010,2018,2026,2034,2042,2050$, \\
& & Pahing & $2058,2066,2074,2082,2090,2098,2106$ \\
\hline
\end{tabular}

From the explanation above, then in the current Javanese calendar, it should have been in the asapon kurup, since Pon Tuesday, 1 suro 1867 or 1 suro 1355 or 24 March 1936. This means that at this time it has been used asapon kurup for 86 years (Java ). However, people who still use the aboge kurup in the calendar will be different in a way. It could be that the Aboge calendar will be a few days apart, usually one day from the Javanese calendar, and or one to two days from the hijri calendar. 
For example, 1 Muharram 1441 hijriah, and 1 suro 1953 Java, fall on Sunday, September 1, 2019. However, in the Aboge Javanese calendar, 1 suro on Monday Kliwon, September 2, 2019.

Whereas Javanese culture is rich in traditions, lelakon and petengan, ${ }^{104}$ which for any purpose need to be calculated in a certain way or formula. As well as having restrictions, one of which is related to the beginning / end of the Javanese year.

\section{Conclusion}

From this discussion we can conclude that

1. Calendar is a list of days, weeks, months of holidays in a year. Calendar is a calculation and division of times in units of time such as years, months, weeks, and days based on certain phenomena to be used as guidance, signs and rules for human activity at all times.

2. By its use, the calendar is divided into the social calendar and the calendar of worship. As seen from the reference system, the calendar is divided into based on the sun (solar calendar), based on the month (lunar calendar) and based on both (luni-solar calendar). Meanwhile, from the easy-complexity of calculations, the calendar is divided into two, the astronomical calendar and the arithmetic calendar.

3. The Javanese calendar is the calendar system used by the Mataram kingdom and its various kingdoms that have been parted and influenced. This calendar combines various calendar systems, such as the Hijri calendar, the Hindu calendar and the Julian calendar.

4. The relevance of the Javanese calendar with the hijri calendar. at least seen from several aspects including them

- Both are based on the circulation of the month.

- The change of the Javanese calendar from the Saka calendar to a monthbased calendar, inspired by the Hijri calendar

- The Javanese calendar was originally intended to facilitate worship.

${ }^{104}$ Ign. Gatut Saksono dan Djoko Dwiyanto, Faham Keselamatan dalam Budaya Jawa,(Yogyakarta: Amtama, 2012), 160. Petengan is a way of calculating good moments (times) and dates, taking into account the five pasaran days, important dates determined in the existing calendar systems, which are used by the Javanese for various purposes. 
5. The Javanese Aboge calendar, is a Javanese calendar that uses the aboge kurup, which is the determination based on the standard that every alip year begins with wage wednesday, and the holidays will be on the wage pasaran. The aboge calendar is no longer used in the Javanese calendar, because currently the Javanese calendar is on the Asapon kurup.

\section{E. Bibliography}

Abdul Karim, Mengenal Ilmu Falak, Semarang: Intra Pustaka Utama, 2006

Abdul Mufid, Moderasi Beragama Perspektif Yusuf al-Qaradawi Kajian Interdisipliner tentang Wacana Penyatuan Hari Raya, Purwokerto: Pena Persada, 2019

Ahmad Fadholi, Ilmu Falak Dasar, Semarang: El-Wafa, 2017

Ahmad Izzuddin, Ilmu Falak Praktis Metode Hisab Rukyat Praktis dan Solusi Permasalahannya, Semarang: Pustaka Al-Hilal, 2012 ,Sistem Penanggalan, Semarang: Cv. Karya Abadi, 2015

Al-Atsary, Abu Yusuf, pilih Hisab atau Rukyah? Sebuah Telaah Ilmiyah dalam Menjawab Polemik Seputar Penentuan Puasa dan Hari Raya,Solo: Pustakan Darul Muslim, tt

Al-Qu'an dan terjemahnya,Mujamma' al-malikFahd li thiba'at al-mush-ha ay-syarif madinah alMunawwarah Po box 6262 kerajaan Arab Saudi, 1433 H

Anisah Budiwati, Formulasi Kalender Hijriah dalam Pendekatan Historis-Astronomis, Disertasi, Universitas Islam Negeri Semarang, 2019

, Teori dan Aplikasi Ilmu Falak di Perguruan Tinggi Islam,Yogyakarta: Buku Ajar Universitas Islam Indonesia, 2017

105

Aryono, Pada mulanya adalah waktu, diakses tanggal 10 Februari 2020, https:/historia.id.cdn.ampprojrct.org

Astronomy defined and explained, Collins Dictionary of Astronomy,British: The Macmillan Dictionary, 2012

Baharuddin Zainal, Ilmu Falak, Selangor: Dawama Sdn. Bhd., 2004 ,Ilmu Falak Teori, Praktik dan Hitungan, Kuala Terengganu: Yayasan Islam Terengganu, 2003

Bashori, Muh. Hadi, Penanggalan Islam, Peradaban tanpa Penanggalan, Inikah pilihan kita?, Jakarta: Gramedia, 2013

Butar-Butar, Arwin Juli Rakhmadi, Kalender Islam, Lokal ke Global, Problem dan Prospek,Medan: OIF Umsu, 2016

105 Anton Rimanang, Pranatamangsa Astrologi Jawa Kuno, ed. Andreas Troi Prasetya Yogyakarta: Kepel Press, 2016

Al-Hilal: Journal of Islamic Astronomy, Vol. 2, No. 2, Tahun 2020

p-ISSN : 2775-1236; e-ISSN : 2775-2119 
,Kalender sejarah dan Arti Pentingnya dalam Kehidupan, Semarang: bisnis Mulia Konsultama, 2014

Departemen Agama RI, Almanak Hisab-Rukyat, Jakarta; Diroktorat Jendral Bimbingan Masyarakat Islam Kementrian Agama RI, 2010

Djanudji, Penanggalan Jawa 120 tahun Kurup Asapon 24 Maret 1936-25 Agustus 2053, Semarang: Dahara prize, 2013

Hamdani, F. fatwa Rosyadi S.,Ilmu Falak Menyelami makna hilal dalam al-qur'an, Bandung: Unisba, 2017

Hendro Setyanto, Kalender Mandiri sebagai Dasar Kesatuan Kalender Hijriah Internasional, dalam Proseding Seminar Nasional Kalender Islam Global (Pasca Muktamar Turki 2016), Medan: OIF Umsu, 2016

Jamaluddin Abd ar-Raziq, terjemahan Syamsul Anwar, Kalender Kamariah Islam Unifikatif, Yogyakarta: Itqan, 2013

Jani, Muhammad Faizal, Ilmu Falak Fi Ithna Asyara Syahran,Malaysia: tt, 77-80

Kadir, Formula Baru Ilmu falak Penduan Lengkap Ë Praktis, Jakarta: Amzah, 2012

Lutfi Adnan Muzamil, Studi Falak dan Trigonometri Cara Cepat dan Praktis Memahami Trigonometri dalam Ilmu Falak, Yogyakarta: Pustaka Ilmu, 2015

Ma’rifat Iman, Kalender pemersatu Dunia Islam,Jakarta: Gaung Persada Press, 2010

Maskhufa, Ilmu Falaq, Jakarta: Gp Press, 2009

Mohammad Ilyas, Sistem Kalender Islam dari Perspektif Astronomi, Selangor: Percetakan dewan Bahasa dan Pustaka, 1997

Muh. Nasiruddin, Kalender Hijriah Universal, Kajian atas sitem dan prospeknya di Indonesia, Semarang: Al-wafa, 2013

Muhyiddin Khazin, 99 Tanya Jawab masalah Hisab EF Rukyat, Yogyakarta: Ramadhan Press, 2009

,Ilmu Falak; Dalam Teori dan Praktek, Yogyakarta: Buana Pustaka, 2008

Mukti, Wiji Aziz Hari, Ilmu Pengetahuan Bumi dan Antariksa Kajian Sains dan AL-Qur'an, Yogyakarta: Pustaka Pelajar, 2017

Nadirin, Akhmad and Ni'am, M. Ihtirozun, "Date Correction Of Omar Bin Khattab's Death In An Astrnomical Perspective,” Al-Hilal:Journal of Islamic Astronomy 1, 2019

Pratama, Dito Alif, Penentuan Awal Bulan Qomariyah di Indonesia (Studi terhadap keputusan menteri agama RI tentang penetapan awal bulan ramadhan dan syawwal tahun 1998-2012), Dalam Laporan Penelitian Mahasiswa LPM IAIN Walisongo Semarang, 2013

Purwadi dan Siti Maziyah, Horoskop Jawa, Yogyakarta; Media Abadi, 2007

Ruswa darsono, penanggalan Islam Tinjauan Sistem, Fiqih dan Hisab Penanggalan,(Yogyakara Labda Press, tt 
Sakirman, Ilmu Falak Spektrum Pemikiran Mohammad Ilyas, Yogyakarta: Idea Press, 2015

Saksono, Ign. Gatut dan Djoko Dwiyanto, Faham Keselamatan dalam Budaya Jawa, Yogyakarta: Amtama, 2012

Salamun Ibrahim, Almanak Masehi-Hijri 1920-2020M/1339-1439H, Surabaya: Pustaka Progressif, 2006

Sejarah Kalender jawa, Diakses pada tanggal 1 Februari 2020 www.infobudaya.net.

Shofiyullah, Metode Hisab Sullam Al-Nayyirain dalam Perspektif Astronomi, Disertasi, UIN Walisongo Semarang, 2018

Shofwan Jannah, Kalender Hijriah dan Masehi 150 Tahun : 1364-1513H (1945-2090), Yogyakarta: UII Press

Slamet Hambali,Almanak Sepanjang Masa, Semarang: Program Pascasarjana IAIN Walisongo, 2011

Sofwan Jannah, Kalender Hijriah-Masehi 150 Tahun: 1364-1513 H (1945-2090M),Yogyakarta: UII Press, 1994

Sudibyo, Muh. Ma'rufin, Beberapa Pertanyaan tentang (usulan) Kalender Hijriah Persatuan Internasional, dalam Proseding Seminar Nasional Kalender Islam Global (Pasca Muktamar Turki 2016), Medan: OIF Umsu, 2016

Susiknan Azhari dan Ibnar Azil Ibrahim, kalender Jawa Islam:Memaduan Tradisi dan Tuntunan Syar'i, dalam Jurnal Asy-Syir'a, vol 42 no.1 , (2008): 131, diakses tanggal 27 Februari 2020, doi:

,Ensiklopedi Hisab Rukyat, Yogyakarta: Pustaka Pelajar, 2012

,Ilmu Falak Teori dan Praktek, Yogyakarta: Azuardi, 2001

Syamsul Anwar, Interkoneksi Studi Hadis dan Astronomi, Yogyakarta: Suara Muhammadiyyah, 2011

Syarif, Muh Rasywan, Perkembangan Perumusan Kalender Islam Internasional,Disertasi UIN Sunan Kalijaga Yogyakarta, 2017

Tahir, Abdul Hamid, Unsur-unsur Astronomi Praktik untuk Kegunaan Ukur Tanah,Melaka: Syarikat Percetakan Muncul System, 1990

Tasnim Rahman Fitra, Fikih kalender Hijriah Unifikatif, http://www.istinbath.or.id, 2018 : 261, diakses tanggal 10 Februari 2020, doi :https://doi.org/10.20414/ijhi,v17i2.96.

Thomas Djamaluddin, Kalender Hijriah Bissa Memberi Kepaastian Setara dengan Kalender Masehi,dalam seminar Penyatuan Kalender Hijriah (sebuah upaya pencarian kriteria hilal yang objektif ilmiah), Semarang: UIN Walisongo, 2012

,Rekomendasi Jakarta 2017: Upaya mewujudkan kalender Islam Tunggal, diakses tanggal 23 Februari 2020, https://tdjamaluddin.wordpress.com.

Zin, Aizan Ali Mat, Sejarah Astronomi Islam di Malaysia, Kuala Lumpur: Universiti Malaya, 2017

Al-Hilal: Journal of Islamic Astronomy, Vol. 2, No. 2, Tahun 2020

p-ISSN : 2775-1236 ; e-ISSN : 2775-2119 
